IdeAs

Idées d'Amériques

$10 \mid 2017$

États-Unis / Cuba : une nouvelle donne?

\title{
United States - Cuba: a New Deal?
}

Isabelle Vagnoux et Janette Habel

Traducteur : Michael Hinchliffe

\section{CpenEdition}

\section{Journals}

Édition électronique

URL : https://journals.openedition.org/ideas/2295

DOI : 10.4000/ideas. 2295

ISSN : 1950-5701

Cet article est une traduction de :

Etats-Unis - Cuba : Une nouvelle donne ? - URL : https://journals.openedition.org/ideas/2187 [

Autre(s) traduction(s) de cet article :

Estados Unidos - Cuba? Uma fase nova? - URL : https://journals.openedition.org/ideas/2270 [pt]

Estados Unidos-Cuba, iun nuevo orden? - URL : https://journals.openedition.org/ideas/3120 [es]

Éditeur

Institut des Amériques

Référence électronique

Isabelle Vagnoux et Janette Habel, « United States - Cuba: a New Deal? », IdeAs [En ligne], 10 | 2017 , mis en ligne le 19 avril 2018, consulté le 18 octobre 2022. URL : http://journals.openedition.org/ideas/ 2295 ; DOI : https://doi.org/10.4000/ideas.2295

Ce document a été généré automatiquement le 18 octobre 2022

\section{cc) (i) $\Theta$}

Creative Commons - Attribution - Pas d'Utilisation Commerciale - Pas de Modification 4.0 International - CC BY-NC-ND 4.0

https://creativecommons.org/licenses/by-nc-nd/4.0/ 


\title{
United States - Cuba: a New Deal?
}

\author{
Isabelle Vagnoux et Janette Habel \\ Traduction : Michael Hinchliffe
}

1 "But there are laws of political as well as of physical gravitation; and if an apple severed by the tempest from its native tree can not choose but fall to the ground, Cuba, forcibly disjoined from its own unnatural connection with Spain, and incapable of self-support, can gravitate only towards the North American Union, which by the same law of nature cannot cast her off from its bosom." So predicted American Secretary of State John Quincy Adams (Adams J.Q., 1823) with regard to the island of Cuba situated less than 170 kms from Key West. Quincy's "political gravitation" principle applied to a territory considered by some as Florida's southern shore has taken root and made its mark on the asymmetrical, intimate and passionate relationship between Washington and Havana, a relationship often fraught with conflict, never a subject of indifference.

2 Nineteenth century US expansionist ambitions; "civilizing mission"; "aid" towards Cuban independence in 1898; military occupation with attendant economic appropriation; establishment of de facto dependence (in a letter to president Theodore Roosevelt on October 28, 1901, General Wood did indeed write : "There is, of course, little or no real independence left Cuba under the Platt Amendment," (Schoultz L., 2009: 24)); irritation in Washington (in 1906 Theodore Roosevelt expressed his exasperation to his friend Henry L. White: "I am so angry with that infernal little Cuban republic that I would like to wipe its people off the face of the earth" (Schoultz L., 2009: 25)); support extended to Americanized Cuban political leaders; a long concomitant tradition of refuge in the US for Cuban dissidents, whether in opposition to Spain, to certain presidents or, later, to the Castrist regime: thus could be sketched the bold outlines of a very intimate, bilateral history. Can Cuba be seen as a US "neo-colony"? Possibly it can, in many respects. Historian Hugh Thomas (1974) writes of "the United States administration's identification with Batista via his ambassadors and the colonels of the military mission". Washington's support of Batista's dictatorship never really ceased. The weapons embargo set up in March 1958, "too little, too late" (Luxenberg A., 1991), was not respected. The US military mission continued training Batistiano troops right up to the final offensive against Castro (Smith W., 1987). 
The triumph of the revolution in 1959 marked a radical break in the American domination of Cuba. Washington nevertheless attempted to ride this change by appointing a new ambassador, Philip Bonsal, a career diplomat and Latin America specialist who contrasted with his predecessors, all far more concerned with US economic interests than with diplomacy. When the líder máximo made a non-official visit to the East Coast and met with vice-president Nixon in April 1959, history was not pre-ordained. In a summary written for President Eisenhower, Nixon, for all his wellknown anti-communist sentiments, wrote: "Whatever we may think of him, he is going to be a great factor in the development of Cuba and very possibly in Latin American affairs generally. He seems sincere. He is either incredibly naive about communism or under communist discipline - my guess is the former. [...] We have no choice but at least to try to orient him in the right direction." (Nixon R., 1978: 202; CIA, 2013). Ambassador Bonsal agreed with this judgment: "there was not sufficient evidence" in the spring of 1959 to denounce Castro's "secret communism" (Bonsal P., 1971: 60). Better still, there were CIA agents who nursed hopes of conducting regular exchanges with Castro about goings on in Moscow and Beijing (Bonsal P., 1971:64-65). In May 1959 the agrarian reform was promulgated leading to the expropriation of estates over 400 hectares with effects especially on the large American sugar plantations such as United Fruit. Compensations were to take the form of 20 year reimbursable treasury bills. Washington demanded swift and effective compensation. For Castro, it was a question of take it or leave it. These developments signaled the beginnings of hostility between the two countries. In December 1960, against the opinion of Ambassador Bonsal, the United States stopped importing Cuban sugar, whereupon Havana and Moscow published a common communiqué. Diplomatic relations were severed in 1961 with the Washington-imposed embargo already operative. In the context of the Cold War, the Cuba - USSR rapprochement constituted what was probably the direst strategic threat ever experienced by the United States. The Soviet Cuban missile crisis of 1962 was the paroxystic moment in a standoff between two super powers in which Havana itself played a very secondary role (Touze V., 2012). The worst - nuclear war- avoided, the two super powers agreed to concessions. Washington undertook to engage in no military intervention in Cuba, in other words to avoid repeating the previous year's disastrous Bay of Pigs invasion. But with Havana providing active aid to revolutionary movements in Latin America and Africa, Washington sought other means of dealing with the Cuban nuisance. In 1963, Kennedy stated: "I don't accept the view that Mr. Castro is going to be in power in 5 years" (Kennedy J.F., 1963) and all means were deployed against him: throughout the sixties, the embargo and assassination attempts (U.S Congress, 1975: 71-80), and from the 80s onward, diplomatic isolation and media pounding (Radio and later Televisión Martí). All to no avail.

4 From crisis situations to secret negotiations and overtures, the half-century after the Cuban revolution appears as a long succession of lost opportunities, the outcome of which could have been different (NSA, 2003; NSA, 2009; LeoGrande W. \& Kornbluh P., 2015). Various Latin American countries were active on the sidelines. Brazil and Mexico in particular (the latter never having broken off diplomatic relations with Havana) constantly offered mediation. It was partly pressure from Latin American countries that led the Organization of American States to rescind the exclusion of Cuba in 2009. At the same time, discreet negotiations between Cuba and the US resulted in significant agreements on the subject of migration or technical questions in a double-sided relationship that works rather better than official discourse would admit. However, 
aside from a limited lessening in some areas of commerce, the economic embargo remains in place. Since the 1996 Helms-Burton Act (US Congress, 1996) it can no longer be cancelled by the executive without congressional consent.

5 A new stage was reached in 2006 when Fidel, a sick man, withdrew from the exercise of power while retaining the title of head of state. His brother Raúl assumed power and in 2008 became official president. Although Raúl Castro has operated an economic opening of Cuba, the country's political system has seen little significant change, even if political prisoners are occasionally liberated and the population no longer needs authorization to travel outside Cuba. The thawing of relationships between Cuba and the US that seemed so often about to occur was set to do just that in April 2009 when Barack Obama announced: "The United States seeks a new beginning with Cuba", while recognizing it would take time "to overcome decades of mistrust" (Obama B. 2009). Hoping that people to people contacts, openings and exchanges are better vectors of progress than isolation and repression and that they would finally bring to an end the curtailment of democratic freedoms and human rights, Obama slashed a large hole in the repressive arsenal deployed against Cuba. However, in December 2009, the imprisonment by Cuba of Alan Gross ${ }^{1}$, an American citizen accused of espionage, put this first phase on hold. There were heated debates in Washington between CubanAmericans favoring a hardline approach seeking the overthrow of the regime and the proponents of an open position. The second group were motivated not by philanthropy but by hard-headed economic and political realism. With Cuba opening up to foreign investment, there were plenty of American firms and investors keen to join in. And as Obama himself has put it "the notion that the same policies that we put in place in 1961 would somehow still be as effective as they are today in the age of the Internet and Google and world travel doesn't make sense." (Obama B., 2013).

6 Finally, as a result of an intervention by Pope Francis, History moved a little faster. Alan Gross was liberated in December 2014 and on December 17 ("17D"), President Obama announced the decision to resume diplomatic relations with Cuba, to remove Cuba from the list of terrorist supporting states, to increase the number of journeys, the volume of trade and the flow of information towards Cuba. In April 2015, Washington agreed to Cuban participation in the Summit of the Americas and the presidents of both countries met on an historic occasion.

7 In August that year, an American Secretary of State trod the soil of Havana for the first time since 1945. John Kerry made the trip for the official inauguration of the American embassy. In March 2016 on the occasion of the first state visit of an American president to Cuba, Barrack Obama proclaimed: "I have come here to bury the last remnant of the Cold War in the Americas. I have come here to extend the hand of friendship to the Cuban people." (Obama B., 2016). He addressed to Congress an exhortation to remove the embargo. A new era, it seemed, had dawned.

8 The idea of the present dossier on the historic change in bilateral relations between these two "intimate enemies" (Pérez-Stable M., 2010) was conceived at a time when, diplomatic relations having been re-established, normalization appeared to be well on course, barring predictable blockages, particularly in the US Congress. The ground covered in recent years could not have been covered without an alinement of favorable planets (a reshuffle in the composition of the Cuban-American community; pressure brought to bear by US businesses; the economic necessity of the opening initiated by Raúl Castro; the gap left by the weakening of allies such as the USSR and later 
Venezuela; the determination of Latin American countries to put an end to an historical aberration) and the will of two men, Presidents Barack Obama and Raúl Castro. "It takes two to dance a tango". But the dynamic they set in motion has suddenly shifted into lower gear. Recent developments in 2017 make our present project appear in a less optimistic light and justify the question mark in its title. We have president Trump determined to undo much of what his predecessor put in place (White House, 2017), a Republican majority in both houses of Congress which will make the lifting of the embargo much more difficult to bring about, and we have the mysterious ailments suffered by American diplomats posted to Havana (Sullivan M., 2017) which have markedly slowed down activity in the newly opened embassy. Raúl Castro, the other protagonist of the rapprochement is set to quit the presidency in April 2018, though, for the time being, he will remain first secretary of the Communist party (CCP). A new generation is coming to power in Havana and the post-Castro era is already under way. Nevertheless, in spite of the current slow-down, the winds of History are blowing, driving in the direction of normalized relations. A page turns slowly.

9 This trilingual collection offers nine papers from French, Dutch, German, Canadian and American researchers, all specialists of Cuba or international relations, focusing on the decisive factors within each country presiding over the decision to move towards normalized relations, looking also at outside support for the process (from Canada, the Vatican, Latin America, the European Union) and concluding with a double analysis of the prospects of an evolution in relations under the Trump administration.

10 Political analyst Janette Habel contributes the only article centered completely on the Cuban perspective. In it she shows how the process of internal reform, the new aspirations of the population, but also the serious difficulties faced by Brazil and Venezuela, allies (and providers of support) induced Raúl Castro to seek an historic evolution in relations with the US, moreover at a favorable juncture when, for the first time, Washington was no longer demanding regime change or in-depth political reform as a pre-requisite to negociation, even if that aim had not been set aside. From the American perspective, Ted Pïccone, program director at the Brookings think-tank, analyses the reasons why several US interest groups in favor of normalizing relations with Cuba succeeded in gaining the upper hand over policies in place since the sixties and in influencing strategy at the highest level. A third actor is the Cuban American diaspora, notably Florida based, whose members, after exerting decades-long influence over Washington in favor of severity, are now far more inclined to envisage new openings in bilateral relations. This recent development is studied by American sociologist Guillermo Grenier using opinion polls on Cuba carried out at regular intervals over a period of twenty years by the International University of Florida (FIU Cuba Poll).

11 The process of normalization, however, has also been edified on the strength of outside influences that have, with varying results, worked towards ending an anomalous postCold War situation. Canadian political analyst Gordon Mace describes in minute detail how on several occasions in the course of the past half century Ottawa has attempted to bring about a rapprochement with Cuba and to convince Washington to do likewise. But by misfortune, just as Obama began doing just that, the tendency under the conservative government of Stephen Harper was rather towards a hardening of relations thus blocking any concerted approach. The Vatican, on the other hand, on the strength of successful interventions in 1998 and 2012 by Popes John-Paul II and 
Benedict XVI, has played a not inconsiderable role under the first Latin American pontiff Pope Francis, via Monsignor Ortega, archbishop of Havana. Maria Gayte, who specializes in Washington - Vatican relations, provides an analysis of pontifical mediation with reference to the diplomatic priorities of the Holy See. The Latin American context is equally important, with Latin America clearly favorable to the reinstatement of Cuba in the hemispheric concert of nations and to rapprochement with Washington after decades of Cuban "soft power" and the normalization of her relations with Latin American and Caribbean states. Dutch historian Dirk Kruijt describes the "long trek" involved here. Following Latin America's lead, the European Union also appears to usher Washington towards normalization while at the same time playing its own card as "third strategic actor" of an asymmetrical triangle in which a Europe in favor of compromise oscillates, as political analyst Susanne Gratius demonstrates, between alinement with Washington or alinement with Havana as circumstances and its own interior balance of political power dictate.

12 The concluding pieces by two American political scientists deal with the direction of US - Cuba relations in the context of the Trump presidency. William LeoGrande describes how what Obama held to be an "irreversible" evolution is being unraveled by the Trump Administration, although there exist both disagreement within the Administration and, without, certain political forces preventing the new president from wreaking complete havoc in his predecessor's achievements. In his contribution, Jorge I. Dominguez stresses how little Cuba matters to Trump. He argues that Cuba's lack of strategic importance is the factor that allows Washington once more, as previously under G.W. Bush, to call into question the validity of the island's political system. Today, he contends, anything could happen, from restricted, pragmatic cooperation based on common interests to ideological confrontation and possibly even a fresh severing of diplomatic relations.

13 To write on current affairs is to run the risk of having to update what is written at the last minute. We should like to thank our authors for having undertaken this demanding task so as to be able to present to our readers material in direct contact with the latest developments. The opinions expressed here are the sole responsibility of each author.

\section{BIBLIOGRAPHIE}

Adams, John Quincy, Letter from John Quincy Adams, U.S. Secretary of State, to Hugh Nelson, American Minister in Madrid, April 28, 1823, dans Worthington Chauncey Ford, ed., Writings of John Quincy Adams, vol. 7, New York, The Macmillan Company, 1917, p. 373.

Bonsal, Philip W., Cuba, Castro, and the United States, Pittsburgh, University of Pittsburgh Press, 1971.

CIA, « Richard M. Nixon's memorandum on meeting with Fidel Castro, April 19, 1959 », 2013. https://www.cia.gov/library/readingroom/docs/CIA-RDP85-00664R000200130001-5.pdf, consulté le 23 septembre 2017. 
Kennedy, John F., « Remarks and Question and Answer Period Before the American Society of Newspaper Editors », 19 avril 1963, The American Presidency Project, http:// www.presidency.ucsb.edu/ws/?pid=9154, page consultée le 26 novembre 2017.

LeoGrande, William M \& Peter Kornbluh, Back Channel to Cuba. The Hidden History of Negotiations between Washington and Havana, Chapel Hill, The University of North Carolina Press, 2015.

Luxenberg, Alan, « Did Eisenhower push Castro into the arms of the Soviets ?» dans Irving Horowitz (dir.), Cuban Communism, Transaction Publishers 1991.

National Security Archive, Kate Doyle, « Double Dealing. Mexico's Foreign Policy Toward Cuba », 2 mars 2003

https://nsarchive2.gwu.edu/NSAEBB/NSAEBB83/index.htm, consulté le 3 novembre 2017

National Security Archive, Kate Doyle, « Cuba and the United States. Road Map on efforts to improve relations revealed in declassified documents », 22 janvier 2009 https://

nsarchive2.gwu.edu/NSAEBB/NSAEBB269/index.htm, consulté le 3 novembre 2017

Nixon, Richard, The Memoirs of Richard Nixon, New York, Grosset \& Dunlap, 1978.

Obama, Barack, « Remarks by the President at the Summit of the Americas Opening Ceremony ", 17 avril 2009, https://obamawhitehouse.archives.gov/the-press-office/remarks-presidentsummit-americas-opening-ceremony, page consultée le 20 novembre 2017.

Obama, Barack, « Remarks by the President at a DSCC Fundraising Reception Miami », Florida, 8 novembre 2013, http://www.reobama.com/remarks-by-the-president-at-a-dscc-fundraisingreception/, page consultée le 15 décembre 2017

Obama, Barack, «Statement by the President on Cuba Policy Changes », 17 décembre 2014, https://obamawhitehouse.archives.gov/the-press-office/2014/12/17/statement-president-cubapolicy-changes, page consultée le 20 novembre 2017

Obama, Barack, « Remarks by President Obama to the People of Cuba », 22 mars 2016, https:// obamawhitehouse.archives.gov/the-press-office/2016/03/22/remarks-president-obama-peoplecuba, page consultée le 20 novembre 2017.

Pérez-Stable, Marifeli, The United States and Cuba: Intimate Enemies, New York, Routledge, 2010.

Schoultz, Lars, That Infernal Little Cuban Republic. The United States and the Cuban Revolution, Chapel Hill, University of North Carolina Press, 2009.

Smith, Wayne, The Closest of Enemies. A Personal and Diplomatic Account of U.S.-Cuban Relations Since 1957, New York, Norton, 1987

Stoehr, John, « The real story behind Alan Gross's work in Cuba », The Hill, 27 janvier 2015, http://thehill.com/blogs/pundits-blog/international/230794-the-real-story-behind-alan-grossswork-in-cuba, page consultée le 18 décembre 2017.

Sullivan, Mark P., « Cuba: Issues for the 111th Congress », CRS Report for Congress, 4 janvier 2011, https://fas.org/sgp/crs/row/R40193.pdf, page consultée le 18 décembre 2017.

Sullivan, Mark P., « U.S. Response to Injuries of U.S. Embassy Personnel in Havana, Cuba », CRS Insight, 6 octobre 2017, https://fas.org/sgp/crs/row/IN10798.pdf, page consultée le 20 novembre 2017.

Thomas, Hugh, Cuba : la lucha por la libertad, New York,Vintage español, Random House, 2013.

Touze, Vincent, Missiles et décisions: Castro, Kennedy et Khrouchtchev et la crise de Cuba d'octobre 1962, Paris, André Versaille éditeur, 2012. 
U.S. Congress, Senate, Alleged Assassination Plots Involving Foreign Leaders. An Interim Report of the Select Committee to Study Governmental Operations With Respect to Intelligence Activities, 94th Congress, 1st session, 20 novembre 1975.

U.S. Congress, Public law 104-114, Cuban Liberty and Democratic Solidarity Act of 1996, 104th Congress, 12 mars 1996, https://www.congress.gov/104/plaws/publ114/PLAW-104publ114.pdf, page consultée le 2 décembre 2017.

White House, «Fact Sheet on Cuba Policy ", 16 juin 2017, https://www.whitehouse.gov/thepress-office/2017/06/16/fact-sheet-cuba-policy, page consultée le 20 novembre 2017.

\section{NOTES}

1. Alan Gross was a subcontractor for the USAID agency. For the debate on what he was doing, see Sullivan M., 2011; Stoehr J., 2015.

\section{AUTEURS}

\section{ISABELLE VAGNOUX}

Rédactrice-en-chef d'IdeAs, Idées d'Amérique, Isabelle Vagnoux est professeur des Universités à Aix-Marseille, spécialiste de politique étrangère américaine et des relations avec l'Amérique latine. Elle co-dirige à Aix l'Observatoire des relations extérieures du monde anglophone (OREMA) au sein du LERMA (EA 853). isabelle.vagnoux@univ-amu.fr

\section{JANETTE HABEL}

Janette Habel est politiste, spécialiste de Cuba. Après avoir été maître de conférences à l'Université Paris Est, elle est actuellement chercheur, animatrice du groupe de travail sur Cuba à l'Institut des Hautes Etudes de l'Amérique Latine (IHEAL) avec Stéphane Witkowski. janette.habel@wanadoo.fr 